PSYCHOLOGIA ROZWOJOWA, $2019 *$ tom 24 , nr 4, s. 39-56

doi:10.4467/20843879PR.19.021.11727

www.ejournals.eu/Psychologia-Rozwojowa

IZABELA GRZANKOWSKA (iD orcid 0000-0003-2278-8620

Instytut Psychologii, Uniwersytet Kazimierza Wielkiego, Bydgoszcz Institute of Psychology, Kazimierz Wielki University in Bydgoszcz izabela.grzankowska@gmail.com

AGNIESZKA KRUCZEK iD orcid 0000-0002-3500-3127

Instytut Psychologii, Uniwersytet Kazimierza Wielkiego, Bydgoszcz Institute of Psychology, Kazimierz Wielki University in Bydgoszcz agnieszka_kruczek@ukw.edu.pl

MICHALINA SOŁTYS (iD orcid 0000-0003-2530-3633

Instytut Psychologii, Uniwersytet Kazimierza Wielkiego, Bydgoszcz Institute of Psychology, Kazimierz Wielki University in Bydgoszcz michalina.soltys@ukw.edu.pl

MAŁGORZATA ANNA BASIŃSKA iD orcidD 0000-0002-6763-8012

Instytut Psychologii, Uniwersytet Kazimierza Wielkiego, Bydgoszcz Institute of Psychology, Kazimierz Wielki University in Bydgoszcz basinska@ukw.edu.pl

\title{
Kwestionariusz Elastyczności w Radzeniu Sobie ze Stresem dla Adolescentów (KERS-14A)
}

\section{Flexibility of Coping with Stress Questionnaire for Adolescents}

(FCSQ-14A)

\begin{abstract}
Coping flexibility is one of the crucial traits determining individual adaptive ability, which is associated with precise adjustment to environmental requirements in a stressful situation. One of the elements that assist in this adjustment is coping flexibility which relies on finding a strategy appropriate for the particular circumstances in which it is to be applied. People who are flexible in coping are characterized by sensitivity to subtle signals coming from the environment, which allow them to change their behavior and act in a more adaptive way. Flexibility in coping has not yet been studied in the Western population of children and adolescents. Due to the lack of methods that could record all signs of flexibility, it was reasonable to start work on a questionnaire that would measure this construct. To provide an equivalent to the Flexibility of Coping with Stress Questionnaire (FCSQ-14) for adults, the Flexibility of Coping with Stress Questionnaire for Adolescents (FCSQ-14A) was developed. Based on the results of pilot studies, assessment of competent judges (CVR $<.6)$, and exploratory factor analysis (EFA) a tool containing 14 items - which examines three dimensions of flexibility: a repertoire of coping strategies, coping competence, and reflexivity - was created. The psychometric properties of the final version of the questionnaire were verified in terms of reliability and validity on a group of
\end{abstract}


adolescents $(N=288)$, ages 14 to $20(M=16.50, S D=1.58)$, in accordance with validation standards. The results showed that FCQ-14A is a valid and reliable method: most values of Cronbach's $\alpha$ coefficients exceed the value of .7, absolute stability is satisfactory, as is both the internal and external validity. The results of Confirmatory Factor Analysis (CFA) in a group of adolescents for a three-factor solution showed that the model is adjusted to the data on an acceptable level $(\mathrm{RMSEA}=.057$; GFI $=.94 ; \mathrm{AGFI}=.92)$.

Keywords: flexibility in coping, adolescents, measurement tool

Słowa kluczowe: elastyczność w radzeniu sobie, młodzież, narzędzie pomiarowe

\section{WPROWADZENIE}

\section{Podstawy teoretyczne}

Według transakcyjnej teorii stresu działania zaradcze są definiowane jako stale zmieniające się poznawcze i behawioralne wysiłki skierowane na radzenie sobie ze specyficznymi wymaganiami wewnętrznymi i zewnętrznymi, które zostały ocenione przez jednostkę jako przekraczające jej zasoby osobiste (Lazarus, 1993). Takie rozumienie radzenia sobie wskazuje, że jest ono procesem, a celem podejmowanych przez jednostkę wysiłków poznawczych i behawioralnych jest skuteczne poradzenie sobie z zaistniałymi obciążeniami. Samoregulacyjny charakter radzenia sobie ze stresem ujawnia się zarówno u dorosłych, jak i na wcześniejszych etapach życia. Badacze wskazują, że w radzeniu sobie istotną rolę odgrywa zaangażowanie, zarówno poznawcze, jak i behawioralne, również u dzieci i młodzieży, adekwatnie do możliwości wynikających z wieku i poziomu rozwoju (Compas, Conno-Smith, Saltzman, Thomsen, Wadsworth, 2001; Lazarus, Folkman, 1984). Wiadomo również, że proces radzenia sobie u dzieci i młodzieży podlega intensywnym zmianom rozwojowym zarówno pod względem liczby dostępnych strategii radzenia sobie, jak i sposobu korzystania z nich. Skuteczność w tym zakresie jest istotnym czynnikiem ochronnym w rozwoju młodego człowieka (Compas i in., 2001; Pilecka, Fryt, 2011).

Richard Lazarus i Susan Folkman (1984) w stworzonym przez siebie modelu stresu i radzenia sobie zwracali uwagę zarówno na aspekty poznawcze, jak i behawioralne. Wyodrębnili w nim trzy rodzaje ocen, które występują po sobie odpowiednio do dynamiki przebiegu transakcji stresowej. Dwie z tych ocen - pierwotna (ang. primary appraisal) i wtórna (ang. secondary appraisal) - są dobrze znane czytelnikowi i często omawiane w literaturze. Lazarus i Folkman (1984, s. 38) wyróżnili jednak jeszcze tzw. ponowną ocenę (ang. reappraisal), która z perspektywy radzenia sobie rozumianego jako proces ukierunkowany na skuteczne poradzenie sobie ze stresem pełni szczególnie ważną funkcję. W trudnej sytuacji jednostka dokonuje przede wszystkim jej oceny jako stresującej bądź nie (ang. primary appraisal), następnie ocenia swoje zasoby zaradcze (ang. secondary appraisal), by po ich zastosowaniu dokonać oceny skuteczności tej strategii (ang. reappraisal) i określić, czy nadal ma do czynienia z sytuacją stresującą. Jeżeli problem nie został rozwikłany, to ocena ponowna przebiega tak samo jak ocena pierwotna, a proces oceny zaistniałej sytuacji pod kątem nasilenia jej trudności i możliwości poradzenia sobie się powtarza. $Z$ tego powodu być może rola reappraisal została niedoceniona, gdyż sami autorzy uznali, że w swej istocie nie różni się ona znacząco od oceny pierwotnej, jedynie występuje w innym momencie procesu zaradczego. $\mathrm{Na}$ ten aspekt związany z oceną skuteczności zastosowanych strategii zaradczych zwrócili uwagę Tsukasa Kato (2001) i Cecilia Cheng (2001). Podkreślili bardzo wyraźnie aspekt efektywności procesu radzenia sobie oraz położyli nacisk na warunki, które prowadzą do jego pomyślnego zakończenia. Zdolność jednostki do zmiany stosowanych strategii radzenia sobie nazwali elastycznością w radzeniu sobie. Zdaniem Cheng (2003) elastyczność odzwierciedla skłonność jednostki do stosowania różnych 
strategii, by sprostać wymaganiom wynikającym ze zmieniających się okoliczności.

Zdarza się także, że pomimo braku zmiany warunków zewnętrznych jednostka decyduje się na wybór innych strategii, ponieważ ocenia podjęte wysiłki jako nieskuteczne. Elastyczność w takim rozumieniu oznacza gotowość jednostki do uważnego monitorowania rezultatów swoich działań zaradczych i natychmiastowej ich zmiany, gdy okażą się nieskuteczne (Kato, 2001; 2012; 2015). Zdaniem Kato (2001; 2015) na elastyczność w radzeniu sobie składają się dwa procesy: ewaluacja radzenia sobie i adaptacyjne radzenie sobie (por. Brandtstädter, Renner, 1990). Podczas procesu ewaluacji jednostka dokonuje oceny skuteczności zastosowanych strategii i ewentualnego zaprzestania ich stosowania, gdy ocena ta jest negatywna. Ten proces spełnia podobną funkcję jak reappraisal w teorii Lazarusa i Folkman (1984). Według Kato na proces adaptacji składa się zdolność do wygenerowania nowego sposobu radzenia sobie i zastosowanie go. $\mathrm{Z}$ powyższego rozumienia jednoznacznie wynika, że w skład obu procesów wchodzą zarówno właściwości poznawcze, jak i behawioralne. Nie ma zatem zmiany zachowania bez elastyczności poznawczej, która jest ważnym aspektem elastycznego radzenia sobie (Cheng, 2001).

Rozumienie elastyczności w radzeniu sobie w takim ujęciu zakłada, że jednostka jest zdolna do krytycznego i twórczego myślenia. Aspekt ten - ważny dla elastyczności w radzeniu sobie zaakcentowała Johanna Vriezekolk ze współpracownikami (2012), poszerzając rozumienie elastyczności w radzeniu sobie, zaproponowane przez innych autorów (Brandtstädter, Renner, 1990; Cheng, 2001). Uważne monitorowanie rezultatów swoich działań i zastanawianie się nad swoją umiejętnością radzenia sobie zakłada zdolność do refleksyjności (Vriezekolk, van Lankveld, Eijsbouts, van Helmond, Geenen, van den Ende, 2012). Krytyczna ocena skuteczności własnych wysiłków jest ważna w przypadku ewentualnego odstapienia jednostki od nieefektywnego działania.

Warunkiem elastyczności w radzeniu sobie jest też dysponowanie stosunkowo szerokim zakresem strategii zaradczych. Należy pod- kreślić, że przekonanie jednostki o posiadaniu szerokiego wachlarza dostępnych strategii odzwierciedla jej zaufanie do siebie, iż dysponuje różnorodnymi zasobami i kompetencjami do radzenia sobie $\mathrm{w}$ trudnych okolicznościach oraz możliwościami elastycznego wykorzystywania tych zasobów w zakresie radzenia sobie ze stresem (Vriezekolk i in., 2012).

Lazarus i Folkman (1984) wskazywali w swojej teorii możliwość wystapienia zmienności zachowań zaradczych ze względu na zmianę sytuacji (tzw. zmienność międzysytuacyjna). Kato $(2012 ; 2015)$ natomiast, opierając się na teorii podwójnego procesu, podkreślał tzw. zmienność wewnątrzsytuacyjną, czyli zmienność zachowań zaradczych bez zmiany sytuacji, lecz jedynie ze względu na brak skuteczności zastosowanych działań.

Konstrukt elastycznego radzenia sobie rozumianego jako podwójny proces, czyli ewaluacja radzenia sobie oraz ponowna adaptacja, zaproponowany przez Kato $(2012 ; 2015)$ nie znajduje odzwierciedlenia $\mathrm{w}$ badaniach przeprowadzonych w populacji kultury zachodniej (Basińska, 2015; Jones, 2015; Sołtys, 2015; Southward, 2014). Postanowiono zatem, opierając się na wyżej wymienionych teoriach, ująć elastyczność w radzeniu sobie znacznie szerzej, z uwzględnieniem wszystkich aspektów, na które wskazują dotychczasowe wyniki badań. Po pierwsze, elastyczne radzenie sobie ze stresem wymaga od jednostki posiadania względnie szerokiego repertuaru strategii radzenia sobie ze stresem. Po drugie, elastyczne radzenie sobie ze stresem zakłada zmienność - określaną za Lazarusem i Folkman (1984) jako zmienność międzysytuacyjna, czyli wykorzystywanie różnych strategii radzenia sobie ze stresem adekwatnie do zmieniających się warunków sytuacyjnych oraz zmienność wewnątrzsytuacyjną, na którą zwracał uwagę Kato (2015), a która wiąże się z wyborem strategii radzenia sobie ze stresem w zależności od zmiany oceny sytuacji stresującej, czyli także wtedy, gdy obiektywne okoliczności nie uległy zmianie. Po trzecie, przejawem elastyczności jest refleksyjne zastanawianie się nad swoim zachowaniem z perspektywy dążenia do osiagnięcia określonego celu i ewentualnej korekty swoich zachowań (z udziałem procesów 
asymilacji i akomodacji), podobnie jak to proponowała Vriezekolk ze współpracownikami (2012).

Należy podkreślić, że elastyczność w radzeniu sobie jest przede wszystkim cechą procesu radzenia sobie i sposobu, w jaki jednostka stosuje strategie radzenia sobie. Przeprowadzone badania wskazują na osobowościowe (Stępka-Tykwińska, Basińska, Sołtys, Piórowska, 2019) i temperamentalne (Kruczek, Basińska, Grzankowska, 2019) podłoże elastyczności w radzeniu sobie ze stresem, a także na jej powiązania z zasobami podmiotowymi (Basińska, Woźniewicz, Warchoł, 2015; Borzyszkowska, Basińska, 2018; Góralska, Basińska, 2019; Janicka, 2015; Kruczek, 2015; Piórowska, Banasik, 2015; Sołtys, 2015). Zważywszy zaś na jej skutki (Cheng, Sun, Mak, 2015; Kato, 2014; Rudnik, Piotrowicz, Basińska, Rashedi, 2019; Vowles, McCracken, Sowden, Ashworth, 2014), można traktować elastyczność także jako zasób podmiotowy. Dzisiejszy stan badań nie pozwala jednak jeszcze na precyzyjne określenie jej natury.

\section{Historia badań nad elastycznością w radzeniu sobie $w$ grupie młodzieży}

Z obserwacji rozwoju zdolności do radzenia sobie ze stresem wynika, że okres dorastania jest czasem, gdy umiejętności radzenia sobie ze stresem mogą być niewystarczające, choć jednocześnie zachodzą również zmiany w zakresie stosowania strategii radzenia sobie (Rew, 2005; Zimmer-Gembeck, Skinner, 2010). W aktywności zaradczej młodych ludzi wraz z wiekiem zmniejsza się udział sposobów radzenia sobie opartych na kontroli pierwotnej, a wzrasta znaczenie kontroli wtórnej (Juczyński, Ogińska-Bulik, 2009; Pilecka, Fryt, 2011). W porównaniu z dziećmi młodzież dysponuje szerszym repertuarem strategii, co szczególnie dotyczy poznawczych możliwości opracowania stresora (Pilecka, Fryt, 2011). Poza tym wzrasta zdolność do poszukiwania strategii dostosowanych do rodzaju działającego stresora (Connor-Smith, Compas, 2002). Wyniki badań prowadzonych wśród osób w wieku 12-84 lat w populacji europejskiej i amerykańskiej wskazują na tendencję do rozwoju wraz z wiekiem bardziej adaptacyjnych i mniej nieprzystosowawczych strategii radzenia sobie (Diehl, Chui, Hay, Lumley, Grühn, Labouvie-Vief, 2014). Ważne jest także to, że elastyczność w radzeniu sobie nie jest powiązana $z$ dysfunkcjami i zaburzeniami (Kato, 2013), ale może być powiązana $z$ równowagą i dojrzałością emocjonalną. Wydaje się też analogiczna do nieobronnego elastycznego radzenia sobie, które jest najbardziej efektywnym stylem zaradczym (Krohne, Egloff, Varner, Burns, Weidner, Ellis, 2000). Przeciwieństwem elastyczności jest usztywnianie zachowań, które obniża skuteczność w przezwyciężaniu stresujących sytuacji (Heszen-Niejodek, 2000). Sztywność w reagowaniu jest związana $\mathrm{z}$ wysokim poziomem lęku, czujności i sztywnego unikania, które towarzyszą większości zaburzeń oraz trudności adaptacyjnych występujących w okresie dorastania, na przykład impulsywności reakcji (Delgado-Rico, Carretero-Dios, Ruch, 2012), usztywnianiu tendencji do unikania $\mathrm{w}$ zaburzeniach odżywiania (Hildebrandt, Grotzinger, Reddan, Greif, Levy, Goodman, Schiller, 2015), nasileniu tendencji depresyjnych u młodzieży (Han, Helm, Iucha, Zahn-Waxler, Hastings. Klimes-Dougan, 2015) oraz stosowaniu strategii radzenia sobie związanych z obwinianiem innych i myśleniem życzeniowym (Blaauwbroek, Zwart, Bouma, Meyboom-de Jong, Kamps, Postma, 2007; Dempsey, 2002). Z powodu niewystarczających umiejętności radzenia sobie ze stresem zdrowie, a czasem nawet życie młodego człowieka może być w niebezpieczeństwie (Rew, 2005). Wydaje się więc niezwykle ważne analizowanie kompetencji do elastycznego radzenia sobie u młodych ludzi, aby na tej podstawie proponować trafne oddziaływania wzmacniające ich zasoby do skutecznego radzenia sobie.

Dotychczasowe badania nad elastycznością w radzeniu sobie dotyczyły głównie osób dorosłych. W tej grupie badanych w populacji japońskiej wielokrotnie została potwierdzona teza, że bardziej elastyczne radzenie sobie prowadzi do bardziej adaptacyjnego funkcjonowania psychicznego i wspiera zachowanie zdrowia fizycznego (Kato, 2015a; 2017; 2017a). 
Elastyczność jako przejaw osobniczej predyspozycji do plastycznego poszukiwania odpowiedzi na potrzebę radzenia sobie z różnorodnymi wymaganiami we wciąż zmieniających się warunkach została rozpoznana już przez ewolucyjnych biologów rozwoju (Huxley, 1958). Wynika z tego pośrednio założenie, że nie tylko dorosły człowiek jest predysponowany do korzystania z szerokiego repertuaru sposobów radzenia sobie, ale że jest to przywilej całego gatunku, można więc poszukiwać kompetencji tego rodzaju również u dzieci i młodzieży. Istotne wydaje się zatem badanie specyfiki elastycznego radzenia sobie z perspektywy różnych etapów rozwoju.

Kato podjął próby wskazania związków elastyczności w radzeniu sobie $\mathrm{z}$ funkcjonowaniem młodzieży. W badaniu zależności między elastycznością radzenia sobie a reaktywnością sercowo-naczyniową (CVR) u starszej młodzieży w sytuacji stresu psychologicznego okazało się, że ekspozycja na trudne zadanie uruchamiała silniejszą odpowiedź fizjologiczna, która jednocześnie była ujemnie skorelowana $\mathrm{z}$ elastycznością $\mathrm{w}$ radzeniu sobie. W innych badaniach tego autora okazało się, że elastyczność $\mathrm{w}$ radzeniu sobie $\mathrm{z}$ bólem menstruacyjnym u młodych dziewcząt była istotnie związana ze zmniejszonymi objawami depresji podczas menstruacji, niezależnie od intensywności odczuwanego bólu i od indywidualnych strategii radzenia sobie (Kato, 2017a). Ponadto adaptacyjne radzenie sobie, czyli jeden z aspektów elastyczności, było istotnie powiązane z niższym poziomem nasilenia symptomów depresji u nastolatków w wieku 13-18 lat (Kato, 2015). Podobne wyniki uzyskano wcześniej w badaniu chińskiej starszej młodzieży i studentów (Zong, Cao, Cao, Shi, Wang, Yan, Abela, Gan, Gong, Chan, 2010). Wydaje się więc, że elastyczność radzenia sobie w ujęciu Kato (2017) pełni funkcję zasobu i czynnika ochronnego dla zdrowia fizycznego w reakcji na stres również u młodzieży.

Przedmiotem dociekań w zakresie elastyczności w radzeniu sobie ze stresem u młodzieży była też elastyczność emocjonalna. W populacji nastolatków w Chinach podjęto próbę walidacji narzędzia do pomiaru elastyczności emocjo- nalnej (Fu, Chow, Li, Cong, 2018). Za pomoca tej skali zbadano związek między elastycznością emocjonalną a dobrostanem psychicznym u nastolatków, którzy doświadczyli trzęsienia ziemi w Syczuanie w 2008 roku. Okazało się, że narzędzie to zapewnia krótką i wiarygodną miarę zdolności regulacji emocji u nastolatków dotkniętych klęskami. Okazało się też, że ich elastyczność emocjonalna była dodatnio skorelowana z elastycznością poznawczą i dobrostanem psychicznym. Stwierdzono pozytywny związek między elastycznością emocjonalna, czyli umiejętnością radzenia sobie z emocjami w sposób dopasowany do wewnętrznych i zewnętrznych wymagań, a dobrym samopoczuciem psychicznym młodych ludzi po doświadczeniu klęski żywiołowej.

Powstaje pytanie: czy podobne zależności występują u młodzieży w kulturze zachodniej? Badania nad elastycznością w radzeniu sobie były prowadzone także $\mathrm{w}$ tym regionie, lecz głównie w populacji osób dorosłych (Borenstein, Hedges, Higgins, Rothstein 2009; Cooper, Hedges, Valentine, 2009; Jones, 2015; Southward, 2014; Vriezekolk i in., 2012).

Dotychczasowe badania wśród dzieci i młodzieży koncentrowały się na elastyczności poznawczej, która w grupie wiekowej 9-15 lat $(M=12.36 \mathrm{roku}, S D=1.77)$ okazała się istotnym predyktorem wtórnej oceny w procesie radzenia sobie (Evans, Kouros, Samanez-Larkin, Garber, 2016). Elastyczność poznawcza młodzieży warunkowała również rozumienie użyteczności nauki matematyki w szkole w stosunku do przyszłego życia (Sharif, 2018).

Badano także elastyczność w radzeniu sobie ze stresem u rodziców dzieci cierpiących z powodu przewlekłego bólu. Okazało się, że poziom elastyczności u rodziców pozostawał $\mathrm{w}$ istotnym związku z nasileniem doznań bólowych ich dzieci (Wallace, Woodford, Connelly, 2016). W rezultacie przeprowadzonych badań zaobserwowano, że bardziej elastyczne reagowanie rodziców w sytuacji bólu dziecka interferuje z odczuciami dziecka, zmniejszając subiektywne odczucie nasilenia jego dolegliwości. W badaniach okazało się także, że elastyczna opieka rodzicielska, nastawiona na wzmacnianie autonomii i samodzielności dzieci chorych na 
fibromialgię, sprzyjała ich równowadze emocjonalnej, bo zwiększała długofalowo skuteczność radzenia sobie dzieci i młodzieży z chorobą.

W badaniach podłużnych obserwowano również wzorce radzenia sobie zgłaszane przez młodzież narażoną na maltretowanie, wychowywaną w rodzinie zastępczej. Wielu badanych młodych ludzi popierało stosowanie więcej niż jednego stylu radzenia sobie ze stresem, co wskazuje na ich potencjalną elastyczność w radzeniu sobie z sytuacjami, w których pojawiają się problemy. Zróżnicowane wybory dotyczące stylu radzenia sobie były w tej grupie związane raczej z rodzajem problemu, ale nie odnotowano statystycznie istotnych różnic międzysytuacyjnych w stylach radzenia sobie. Brano przy tym pod uwagę także pozarodzinne sytuacje społeczne, na przykład akademickie, w tym także zróżnicowane sytuacje sprzyjające (Jackson, Huffhines, Stone, Fleming, Gabrielli, 2017). Potwierdza to wskazaną przez ewolucyjnych biologów rozwoju predyspozycję do plastyczności w dostosowaniu się do warunków zewnętrznych (Huxley, 1958). Nie spełnia to jednak kryteriów elastyczności w radzeniu sobie.

Elastyczność w radzeniu sobie u dzieci i młodzieży dotychczas nie była w zachodniej populacji dzieci i młodzieży badana ze względu na brak stosownego narzędzia pomiaru. Dokonanie takiego pomiaru umożliwia Kwestionariusz Elastyczności w Radzeniu Sobie ze Stresem dla Adolescentów (KERS-14A), przeznaczony dla młodzieży w wieku 14.-20. roku życia prezentowany poniżej.

\section{ETAPY KONSTRUKCJI \\ KWESTIONARIUSZA ELASTYCZNOŚCI W RADZENIU SOBIE ZE STRESEM (KERS-14A)}

Prace nad konstrukcją kwestionariusza do pomiaru elastyczności w radzeniu sobie ze stresem podjęto $\mathrm{w}$ odpowiedzi na nie w pełni satysfakcjonujące wyniki uzyskane w badaniach z użyciem polskiej adaptacji Skali Elastycznego Radzenia sobie ze Stresem autorstwa Kato (Basińska, 2015; Sołtys, 2015). Z doniesień innych badaczy wynika, że narzędzie to ma ograniczoną wartość diagnostyczną w badaniach dotąd przeprowadzanych w innych populacjach kultury zachodniej (Jones, 2015; Southward, 2014). W celu zaoferowania narzędzia, które umożliwi operacjonalizację wszystkich podstawowych aspektów elastyczności w radzeniu sobie (wszechstronności metod zaradczych, zmienności wewnątrzsytuacyjnej i międzysytuacyjnej, ewaluacji procesu zaradczego), a także na podstawie zaprezentowanego $\mathrm{w}$ niniejszym artykule ujęcia teoretycznego (tj. Transakcyjnej Teorii Stresu oraz Teorii Podwójnego Procesu) (Cheng i in., 2015; Kato, 2012; Lazarus, Folkman, 1984; Vriezekolk i in., 2012) zespół ekspertów złożony z ośmiu psychologów-badaczy wygenerował w celu opracowania kwestionariusza wyjściową pulę 49 twierdzeń.

Po przeprowadzeniu badań pilotażowych $(N=88)$ wstępnie odrzucono cztery pozycje o najniższej mocy dyskryminacyjnej, a następnie wdrożono procedurę sędziów kompetentnych (złożonych z pięciu psychologów), których zadaniem była ocena trafności treściowej twierdzeń. W nawiązaniu do przedstawionych podstaw teoretycznych sędziowie dokonywali ocen w czterech kategoriach: wszechstronność stosowanych metod zaradczych, gotowość do zmiany strategii, gdy sytuacja nie ulega zmianie (zmienność wewnątrzsytuacyjna), generowanie najbardziej skutecznych sposobów radzenia sobie (zmienność międzysytuacyjna) oraz ewaluacja procesu zaradczego. Do oceny trafności każdego ze stwierdzeń posługiwali się czterostopniową skalą (gdzie 0 oznacza twierdzenie w pełni nieadekwatne, a 4 - twierdzenie w pełni adekwatne). Dla każdej pozycji wyliczono współczynnik trafności treściowej (content validity ratio - CVR) (Lawshe, 1975, za: Hornowska, 2001). Na podstawie wyników ocen sędziów kompetentnych usunięto pozycje, dla których wskaźniki CVR $<.6$, średnia ocen ekspertów zaś nie przekraczała wartości 3 (przy skali 0-4). Jako uzupełnienie tych analiz przeprowadzono eksploracyjną analizę czynnikową (EFA) oraz analizę rzetelności w wyróżnionych kategoriach. Ich wyniki pozwoliły na wstępne zweryfikowanie trafności teoretycznej pozycji o zbliżonym brzmieniu - wyeliminowano te 
z nich, które cechowały się niższymi ładunkami czynnikowymi oraz miały niższą moc dyskryminacyjną. Łącznie pozostawiono 35 twierdzeń.

Ze względu na ograniczony zakres wniosków dotyczący struktury wewnętrznej kwestionariusza w pierwszym badaniu pilotażowym w kolejnym badaniu przeprowadzono EFA na próbie 230 osób. Wyniki serii kilkudziesięciu analiz, na podstawie których kolejno usuwano pozycje o najniższych ładunkach czynnikowych, wykazały, że najbardziej adekwatne jest rozwiązanie trzyczynnikowe, gdzie wartość własna (ang. eigenvalues) przekraczała wartość 1 (zmienność wewnątrz- i międzysytuacyjna, w odróżnieniu od założeń teoretycznych, na poziomie analiz statystycznych nie były reprezentowane przez odrębne czynniki). Trzy wyodrębnione w badaniach pilotażowych czynniki wyjaśniały łącznie 55,97\% wariancji: czynnik 1 (szeroki repertuar strategii radzenia sobie) - 40,87\%, czynnik 2 (kompetencje zaradcze) - $8,03 \%$ oraz czynnik 3 (ewaluacja procesu radzenia sobie, refleksyjność) - 7,03\%. Wartości ładunków czynnikowych dla poszczególnych twierdzeń kwestionariusza w trzech głównych kategoriach mieściły się w przedziale 0,53-0,80. Po dokonaniu krytycznej, jakościowej analizy treści pozostałych 17 twierdzeń zespół badawczy podjął decyzję o odrzuceniu jednej pozycji o niejednoznacznym brzmieniu oraz o wyeliminowaniu jednego twierdzenia o złożonej językowo konstrukcji ze względu na potencjalną trudność $\mathrm{w}$ jego odbiorze przez badanych, a także w celu zredukowania dysproporcji w liczbie itemów reprezentujących dany czynnik. Zdecydowano się również na usunięcie jednej pozycji odwróconej, która w najmniejszym stopniu korelowała z resztą twierdzeń podskali opisującej wszechstronność repertuaru strategii i miała niższy ładunek czynnikowy.

\section{KWESTIONARIUSZ ELASTYCZNOŚCI W RADZENIU SOBIE ZE STRESEM DLA ADOLESCENTÓW (KERS-14A) - OPIS NARZĘDZIA}

W ostatecznej wersji kwestionariusz KERS-14A składa się z 14 stwierdzeń (załącznik nr 1), do których badany ma się ustosunkować przez określenie, jak często każde go dotyczy, wybierając jedną z odpowiedzi: 0 - nigdy nie dotyczy, 1 - czasami dotyczy, 2 - często dotyczy i 3 -zawsze dotyczy. Miarą oceny elastyczności w radzeniu sobie jest wynik ogólny uzyskany przez badanego. Im jest on wyższy, tym wyższa jest ocena badanego dotycząca własnej elastyczności w radzeniu sobie ze stresem. Poza ogólną oceną elastyczności odpowiedzi badanego stanowią również podstawę oceny elastyczności w jej podwymiarach wyrażonych w trzech podskalach kwestionariusza. W wersji dla młodzieży, która odnosi się do osób w wieku 14-19 lat, a w przypadku młodych osób uczących się w szkole średniej - do 20. roku życia, wyodrębniono podskale: Repertuar, Kompetencje zaradcze i Refleksyjność.

W wersji dla młodzieży KERS-14A na wynik w podskali Repertuar (ang. Repertoire) składają się odpowiedzi na pytania $\mathrm{nr} 3,4,5,7,8$, 11. Im wyższy wynik uzyskał badany w tym wymiarze, tym większe jest jego przekonanie o własnej zdolności poszukiwania i stosowania strategii radzenia sobie ze stresem, zarówno wewnątrzpsychicznych, jak i behawioralnych, które mogą zapewnić skuteczne rozwiązanie problemu oraz zdolność do zmiany sposobu radzenia sobie, gdyby wcześniej zastosowana metoda okazała się nieskuteczna. Skala ta odzwierciedla więc ocenę własnej skłonności do zmiany strategii radzenia sobie w zależności od sytuacji zewnętrznej (zmienność międzysytuacyjna) oraz wykorzystania różnych strategii $\mathrm{w}$ razie zmieniających się okoliczności wewnątrzpsychicznych jednostki podczas jej transakcji z otoczeniem (zmienność wewnątrzsytuacyjna).

Wynik w podskali Kompetencje zaradcze (ang. Coping competences), specyficznej dla grupy młodzieży, uzyskuje się na podstawie odpowiedzi badanego na pytania nr 2, 6, 10, 13 . Pozwala on zmierzyć przekonanie jednostki na temat własnych zdolności znajdowania odpowiednich środków zaradczych i zastosowania ich, gdy zajdzie taka potrzeba. Im wyższy jest wynik w tej podskali, tym wyższa jest ocena własnych kompetencji do radzenia sobie ze stresem oraz przekonanie o możliwości skutecznego poradzenia sobie. 
Wyniki w podskali Refleksyjność (ang. Reflexivity) w wersji dla młodzieży oblicza się na podstawie odpowiedzi na pytania nr 1 , 9, 12, 14. Pozwalają one na sprawdzenie, czy badany zdaje sobie sprawę $\mathrm{z}$ refleksji wobec zastosowanych strategii ze względu na ważne dla siebie wartości i cele, łącznie z zaakceptowaniem zaistniałej trudnej sytuacji oraz w jakim stopniu badany jest skłonny dać sobie czas i zastanawiać się nad stosowanym sposobem radzenia sobie.

Struktura czynnikowa kwestionariusza może być rozumiana jako charakterystyka poszczególnych elementów procesu radzenia sobie, którego właściwością jest elastyczność w zakresie działań zaradczych (Cheng, 2001; Kato, 2002). Wydaje się, że z tej perspektywy $\mathrm{w}$ procesie radzenia sobie $\mathrm{z}$ uwzględnieniem elastyczności w trudnej sytuacji zewnętrznej lub wewnętrznej dochodzi do poszukiwania sposobów jak najskuteczniejszego poradzenia sobie z nią (Repertuar). Towarzyszy temu ocena własnych kompetencji w zakresie znajdowania i skutecznego stosowania różnych środków zaradczych (Kompetencje zaradcze) oraz refleksja nad rezultatem podjętych działań w odniesieniu do ważnych dla jednostki celów i wartości (Refleksyjność). Jest to zgodne z koncepcją teoretyczną elastyczności w radzeniu sobie, a struktura czynnikowa w grupie młodzieży ujawnia specyficzną dla niej sekwencję czynników, wśród których istotna jest ewaluacja własnych kompetencji zaradczych, czego nie odnajduje się w strukturze tego konstruktu w grupie osób dorosłych (Basińska i in., 2019).

\section{CHARAKTERYSTYKA PSYCHOMETRYCZNA KERS-14A}

Właściwości psychometryczne ostatecznej wersji kwestionariusza określono na podstawie badań prowadzonych w 2017 roku, których celem była walidacja testu mogącego służyć jako wartościowe narzędzie pomiaru elastyczności w radzeniu sobie ze stresem zarówno u dorosłych, jak i w grupie młodzieży. W związku $\mathrm{z}$ tym równolegle przeprowadzono badania w siedmiu grupach osób dorosłych: czterech grupach klinicznych, dwóch grupach zawodowych podwyższonego ryzyka, wśród zdrowych osób dorosłych ${ }^{1}$ oraz w grupie adolescentów.

W badaniu walidacyjnym wśród młodzieży wzięło udział łącznie 288 osób, w tym 131 chłopców oraz 155 dziewcząt w wieku 14.-20. roku życia. Średnia wieku badanych wyniosła $M=16.50(S D=1,58)$, przy czym średnia wieku dziewcząt $(M=16.53 ; S D=1.41)$ i chłopców $(M=16.59 ; S D=1.77)$ była zbliżona $(t=-.74$; $p=.46)$. Największa grupa badanej młodzieży uczęszczała do liceum ogólnokształcącego ( $n=135 ; 46.88 \%)$, a znaczna do technikum ( $n=73 ; 25.34 \%$ ). Uczniowie gimnazjum stanowili trzecią pod względem liczebności grupę $(n=78 ; 27.08 \%)$. Charakterystykę badanych ze względu na płeć i ścieżkę kształcenia przedstawia tabela 1 .

Tabela 1. Liczebność badanych adolescentów z uwzględnieniem ścieżki kształcenia i płci

\begin{tabular}{|l|c|c|}
\hline \multicolumn{1}{|c|}{ Rodzaj szkoły } & $\begin{array}{c}\text { Liczba osób } \\
(N=288)\end{array}$ & $\%$ \\
\hline Gimnazjum & 78 & 27.08 \\
\hline Liceum & 135 & 46.88 \\
\hline Technikum & \multicolumn{1}{|c|}{2} & .69 \\
\hline Braki Dziewczęta $(n=155)$ \\
\hline \multicolumn{2}{|c|}{32} & 20.51 \\
\hline Gimnazjum & \multicolumn{1}{|c|}{30} & 58.33 \\
\hline Liceum & 2 & 19.87 \\
\hline Technikum & 45 & 1.28 \\
\hline Braki & 1 & 34.35 \\
\hline \multicolumn{2}{|c|}{ Chłopcy $(n=131)$} & .76 \\
\hline Gimnazjum & 44 & 33.59 \\
\hline Liceum & 41 & 31.29 \\
\hline Technikum & 45 \\
\hline Braki &
\end{tabular}

Źródło: opracowanie własne

Poniżej zostały zaprezentowane statystyki opisowe oraz parametry rozkładu wyników uzyskanych w wyniku ogólnym i podskalach 
Tabela 2. Statystyki opisowe i parametry rozkładu wyniku ogólnego oraz wyników uzyskanych w podskalach Kwestionariusza Elastyczności w Radzeniu sobie ze Stresem dla Adolescentów w badanej grupie młodzieży $(N=288)$

\begin{tabular}{|l|c|c|c|c|c|c|}
\hline \multicolumn{1}{|c|}{ Skale KERS-14A } & $M$ & $S D$ & Min. & Maks. & SKE & K \\
\hline Wynik ogólny - Elastyczność & 22.04 & 8.46 & 1 & 42 & .15 & -.38 \\
\hline Podskala Repertuar & 6.05 & 2.65 & 0 & 12 & .19 & -.36 \\
\hline Podskala Kompetencje zaradcze & 9.44 & 4.30 & 0 & 18 & .08 & -.51 \\
\hline Podskala Refleksyjność & 6.55 & 2.72 & 0 & 13 & .08 & -.52 \\
\hline
\end{tabular}

Źródło: opracowanie własne.

Kwestionariusza Elastyczności w Radzeniu Sobie ze Stresem dla Adolescentów w grupie młodzieży (zob. tabela 2).

\section{Rzetelność KERS-14A}

Rzetelność KERS-14A określono, wykorzystując metodę ustalenia zgodności wewnętrznej kwestionariusza. Zgodność wewnętrzną dla pomiaru ogólnego elastyczności w radzeniu sobie u młodzieży w KERS-14A i jej podwymiarów ustalono na podstawie wskaźnika $\alpha$ Cronbacha, który obliczono dla ogólnego wyniku opartego na odpowiedziach badanych na wszystkie stwierdzenia w kwestionariuszu oraz dla trzech wyróżnionych podskal (zob. tabela 3).

Tabela 3. Wartości współczynników zgodności wewnętrznej ( $\alpha$ Cronbacha) poszczególnych wymiarów KERSS-14A w grupie młodzieży $(N=288)$

\begin{tabular}{|l|c|}
\hline \multicolumn{1}{|c|}{ Wymiar KERS-14A } & $\alpha$ Cronbacha \\
\hline Repertuar & .87 \\
\hline Kompetencje zaradcze & .69 \\
\hline Refleksyjność & .72 \\
\hline Wynik ogólny ERS* & .89 \\
\hline
\end{tabular}

*ERS - elastyczność w radzeniu sobie

Źródło: opracowanie własne.

Uzyskane współczynniki zgodności wewnętrznej wskazują na ogólną wysoką rzetelność skali KERS-14A, gdyż większość wartości współczynników $\alpha$ Cronbacha $>$.7. Dla wyniku ogólnego wskaźnik ten jest najwyższy $(\alpha=.89)$ w porównaniu ze współczynnikami uzyskanymi dla podwymiarów. Spośród podwymiarów największą rzetelność uzyskała podskala Repertuar $(\alpha=.87)$, która tworzy najliczniejsza grupa itemów (6 pozycji) o spójnej treści. Kryterium wysokiej rzetelności spełnia również pomiar w skali Refleksyjności $(\alpha=.72)$, choć jest oparty na mniejszej liczbie itemów (4 pozycje) prawdopodobnie ze względu na ich jednorodność treściową. Skala Kompetencje zaradcze wykazuje natomiast nieco obniżoną rzetelność $(\alpha=.69)$, co może być przede wszystkim związane z tym, że jest wymiarem złożonym treściowo, a opartym również na wynikach uzyskanych w niewielu itemach (4 pozycje). Mimo to jej spójność pozostaje dostatecznie wysoka, aby traktować wyniki uzyskane w tej skali jako adekwatne do opisanego konstruktu. Jednocześnie warto ponownie zwrócić uwagę, że jest to podwymiar elastyczności w radzeniu sobie, który w pracy nad konstrukcją kwestionariusza wyodrębniono jedynie u młodzieży. Nasuwa to pytania o znaczenie specyfiki adolescencji dla rozumienia przebiegu procesu elastycznego radzenia sobie na tym etapie rozwoju.

W dotychczasowych badaniach prowadzonych w grupie młodzieży i młodych dorosłych stabilność w czasie okazała się satysfakcjonująca $(r=.70 ; p<.001)$. Stabilność bezwzględna skonstruowanego narzędzia została oceniona na podstawie wyników 29 studentów (23 kobiet, 7 mężczyzn) w wieku 19-23 lat $(M=21.76$; $S D=.97)$, a odstęp czasu między pierwszym a drugim pomiarem wynosił 8 tygodni. Analizę korelacji Pearsona przeprowadzono w stosunku do wyniku ogólnego opartego na odpowiedziach 
badanych w stosunku do 14 stwierdzeń, które są tożsame $\mathrm{z}$ wersją narzędzia dla dorosłych i młodzieży (KERS-14 i KERS-14A). Poza tym zbadano wskaźniki korelacji Pearsona dla poszczególnych czynników, ale jedynie w odniesieniu do charakterystyki podskal dla grupy osób dorosłych (KERSS - 14). Pomiar stabilności bezwzględnej można więc odnieść do grupy młodzieży jedynie w zakresie wyniku ogólnego elastyczności w radzeniu sobie, który wynosi $r=.70$ przy $\mathrm{p}<.001(N=29)$.

Wynik uzyskany metodą test-retest wskazuje więc na zadowalającą stabilność w czasie elastyczności w radzeniu sobie ze stresem na poziomie ogólnym w populacji adolescentów i młodych osób dorosłych. Konieczne jest zatem wdrożenie w najbliższej przyszłości procedury ustalenia stabilności bezwzględnej z uwzględnieniem struktury czynnikowej KERS-14A.

Tabela 4. Struktura czynnikowa KERS-14A - wyniki eksploracyjnej analizy czynnikowej $(\mathrm{N}=288)$; wyróżniono ładunki czynnikowe włączone do poszczególnych podskal

\begin{tabular}{|c|c|c|c|}
\hline \multirow{2}{*}{$\begin{array}{c}\text { Nr } \\
\text { stwierdzenia }\end{array}$} & \multicolumn{3}{|c|}{ Ładunki czynnikowe } \\
\hline & Czynnik 1 & Czynnik 2 & Czynnik 3 \\
\hline 1 & .14 & .49 & .53 \\
\hline 2 & .14 & .63 & -.24 \\
\hline 3 & .72 & .19 & .17 \\
\hline 4 & .60 & .32 & .30 \\
\hline 5 & .81 & .16 & .16 \\
\hline 6 & .15 & .77 & .22 \\
\hline 7 & .76 & .17 & .20 \\
\hline 8 & .77 & .10 & .07 \\
\hline 9 & .22 & .04 & .71 \\
\hline 10 & .49 & .62 & .12 \\
\hline 11 & .65 & .16 & .42 \\
\hline 12 & .22 & .11 & .74 \\
\hline 13 & .21 & .57 & .43 \\
\hline 14 & .44 & .27 & .54 \\
\hline
\end{tabular}

Źródło: opracowanie własne.

\section{Trafność KERS-14A}

Trafność skali KERS-14A została zbada za pomocą eksploracyjnej analizy czynnikowej (na etapie drugiego badania pilotażowego; tabela 4), a na etapie właściwego badania walidacyjnego - konfirmacyjnej analizy czynnikowej, analizy interkorelacji podskal oraz analizy współczynników korelacji KERS-14A z innymi testami jako zewnętrznym kryterium, jak również analizy międzygrupowych różnic średnich (por. Cronbach, Meehl, 1955/2005, za: Brzeziński, 2012).

\section{Trafność wewnętrzna}

Wyłoniona w eksploracyjnej analizie czynnikowej struktura KERS-14A jest odmienna od struktury wyodrębnionej $\mathrm{w}$ grupie osób dorosłych, choć zawartość treściowa obu wersji jest tożsama. Układ poszczególnych pozycji testowych w wyłonionych czynnikach w grupie młodzieży okazał się podobny w zakresie dwóch skal: Repertuar i Refleksyjność. Jako trzeci wymiar w grupie młodzieży ujawniła się skala Kompetencje zaradcze, w którym w treści stwierdzeń dominuje ocena własnych umiejętności zaradczych. W grupie osób dorosłych we wszystkich badanych grupach klinicznych i nieklinicznych odpowiednikiem tej skali jest przekonanie o posiadaniu szerokiego repertuaru strategii zaradczych (skala Zmienność), które dzięki temu uzdalniają jednostkę do skutecznego radzenia sobie z zaistniałą trudną sytuacją (Basińska, Przyborowska-Stankiewicz, Kruczek, Liebert, 2019).

\section{Ocena dopasowania modelu}

W badaniu młodzieży przeprowadzono również konfirmacyjną analizę czynnikową (CFA). Estymację modelu dla tej grupy wykonano metodą największej wiarygodności (Maximum Likehood-ML).

Wyniki analizy $C F A$ przeprowadzonej w grupie młodzieży dla rozwiązania trzyczynnikowego wykazały, że model jest umiarkowanie dopasowany do danych $\left(d f=74 ; \chi^{2}=157.61\right.$; $p<.001$, RMSEA $=.057,90 \%$ CI [.045; .070], $C F I=.96 ; G F I=.94, A G F I=.92)($ Załącznik 1). 


\section{Interkorelacje podskal KERS-14A}

W celu sprawdzania trafności teoretycznej narzędzia w grupie młodzieży $(N=288)$ zastosowano ponadto analizę macierzy korelacji podskal. Współczynniki korelacji Pearsona w tej grupie wskazują na umiarkowane powiązania między poszczególnymi podskalami KERS-14A. Najsilniejszy związek wykazano między Repertuarem a Refleksyjnością $(r=.64)$, a nieco słabszy na zbliżonym poziomie między Repertuarem a skalą Kompetencje zaradcze $(r=.59)$ i skalą Kompetencje zaradcze a Refleksyjność $(r=.57)$.

\section{ANALIZA MIECDZYGRUPOWYCH RÓŻNIC ŚREDNICH WYNIKÓW KERS-14A}

Porównania międzygrupowe dotyczyły różnic W zakresie ogólnego poziomu elastyczności w radzeniu sobie ze stresem i jej poszczególnych wymiarów ze względu na płeć $\mathrm{i}$ wiek badanej młodzieży. Wyniki analiz wykazały, że dziewczęta i chłopcy uzyskali wynik ogólny elastyczności w radzeniu sobie na podobnym poziomie, a także wyniki podobnej miary w podskalach Repertuar i Refleksyjność. Adolescenci różnią się istotnie między sobą ze względu na płeć w jednym wymiarze elastyczności w radzeniu sobie, czyli Kompetencje zaradcze. Dziewczęta bardziej krytycznie oceniają swoje możliwości pod tym względem niż chłopcy (tabela 5).
Podziału grupy ze względu na wiek dokonano z uwzględnieniem kryterium rozwojowego, przyjmując granicę między 16. a 17. rokiem życia jako właściwą dla okresu średniej (pełnej) i późnej adolescencji (Obuchowska, 2002; Oleszkowicz, Senejko, 2013). Z tego powodu wyróżniono dwie grupy wiekowe: młodszą w wieku od 14. do 16. roku życia $(M=15.22$; $S D=.72 ; n=143)$ i starszą w wieku od 17. do 20 . roku życia $(M=17.96 ; S D=.83 ; n=143)$. Różnica wieku między grupami była istotna statystycznie $(t=29.78 ; p<.001)$. Okazało się jednak, że wiek badanej młodzieży nie różnicuje istotnie wyników ogólnej elastyczności w radzeniu sobie ani też $\mathrm{w}$ żadnym $\mathrm{z}$ trzech wymiarów KERS-14A (tabela 6), choć w wymiarze Refleksyjność ujawniła się tendencja związana z nieco wyższym poziomem Refleksyjności w starszej grupie adolescentów $(t=-1.95 ; p=.052)$. Jest to zgodne $z$ ustaleniami psychologii rozwoju dotyczącymi zmian w poznawczym funkcjonowaniu młodzieży w okresie adolescencji, która wraz z wiekiem rozwija zdolność do myślenia abstrakcyjnego, zdolność do refleksji, a w związku z tym do autorefleksji. Jednocześnie z wiekiem zmniejsza się egocentryzm w myśleniu na rzecz jego obiektywizacji i realizmu (Brzezińska, Appelt, Ziółkowska, 2008; Obuchowska, 2002; Oleszkowicz, Senejko, 2013).

Trafność zewnętrzna. Trafność zewnętrzną (zbieżną) KERS-14A ustalono przez porównanie wyników z wynikami badania młodzieży uzyskanych z zastosowaniem Kwestionariusza Elastyczności Poznawczej Johna P. Dennisa i Jenifer S. Vander Wal (2010) w polskiej adaptacji

Tabela 5. Różnice w zakresie elastyczności w radzeniu sobie ze stresem związane z płcią młodzieży (t-Studenta; $N=266 ; d f=264$ )

\begin{tabular}{|l|c|c|c|c|c|c|}
\hline \multirow{2}{*}{ Skale KERS-14A } & \multicolumn{2}{|c|}{$\begin{array}{c}\text { Dziewczęta } \\
(n=149)\end{array}$} & \multicolumn{2}{c|}{$\begin{array}{c}\text { Chłopcy } \\
(n=117)\end{array}$} & \multicolumn{2}{c|}{ Różnice $(d=.28)$} \\
\cline { 2 - 7 } & $M$ & $S D$ & $M$ & $S D$ & $t$ & $p$ \\
\hline Wynik ogólny ERS & 20.94 & 8.059 & 22.64 & 8.771 & -1.64 & .101 \\
\hline Repertuar & 8.93 & 4.367 & 9.69 & 4.356 & -1.42 & .156 \\
\hline Poczucie Kompetencji & 5.61 & 2.451 & 6.36 & 2.827 & -2.31 & .022 \\
\hline Refleksyjność & 6.40 & 2.539 & 6.59 & 2.974 & -.55 & .581 \\
\hline
\end{tabular}

Źródło: opracowanie własne. 
Tabela 6. Różnice w zakresie elastyczności w radzeniu sobie ze stresem związane z wiekiem młodzieży (t-Studenta; $N=286 ; d f=284$ )

\begin{tabular}{|l|c|c|c|c|c|c|}
\hline \multirow{2}{*}{ Skale KERS-14A } & \multicolumn{2}{c|}{$\begin{array}{c}\text { Młodsi } \\
(n=143)\end{array}$} & \multicolumn{2}{c|}{$\begin{array}{c}\text { Starsi } \\
(n=143)\end{array}$} & \multicolumn{2}{c|}{$\begin{array}{c}\text { Różnice } \\
(d=.23)\end{array}$} \\
\cline { 2 - 7 } & $M$ & $S D$ & $M$ & $S D$ & $t$ & $p$ \\
\hline Wynik ogólny ERS & 21.12 & 8.348 & 22.26 & 8.462 & -1.105 & .270 \\
\hline Repertuar & 9.04 & 4.271 & 9.50 & 4.478 & -.871 & .384 \\
\hline Poczucie Kompetencji & 5.93 & 2.608 & 5.95 & 2.691 & -.058 & .954 \\
\hline Refleksyjność & 6.15 & 2.690 & 6.81 & 2.759 & $-1,954$ & .052 \\
\hline
\end{tabular}

Źródło: opracowanie wsłane.

Krzysztofa Piórowskiego i współpracowników (2017). Jest to kwestionariusz, który umożliwia ocenę elastyczności poznawczej w ogólnym pomiarze oraz dwóch podskalach szczegółowych. Na całość elastyczności poznawczej składają się dwa wyróżnione wymiary. Jest to skala Kontroli, która mierzy tendencje do postrzegania sytuacji trudnych jako możliwych do kontrolowania oraz skala Alternatyw, która pozwala ocenić zdolność do dostrzegania i generowania wielu alternatywnych rozwiązań.

Ze względu na przedmiot pomiaru obu inwentarzy wydaje się więc prawdopodobne założenie o przynajmniej umiarkowanej korelacji wyników uzyskanych z ich zastosowaniem. Uczyniono także założenie, że skala Repertuar będzie w wysokiej korelacji ze skalą Alternatyw

Tabela 7. Współczynniki korelacji pomiędzy wynikami Kwestionariusza Elastyczności w Radzeniu Sobie a Kwestionariusza Elastyczności Poznawczej w grupie młodzieży $(N=211)$

\begin{tabular}{|l|c|c|c|}
\hline $\begin{array}{c}\text { KEP } \\
\text { KERS-14A }\end{array}$ & $\begin{array}{c}\text { Skala } \\
\text { kontroli }\end{array}$ & $\begin{array}{c}\text { Skala } \\
\text { alternatyw }\end{array}$ & $\begin{array}{c}\text { Elastyczność } \\
\text { poznawcza }\end{array}$ \\
\hline Repertuar & $.34 * * *$ & $.33 * * *$ & $.41 * * *$ \\
\hline $\begin{array}{l}\text { Kompetencje } \\
\text { zaradcze }\end{array}$ & $.57 * *$ & $.30^{* * *}$ & $.50^{* * *}$ \\
\hline Refleksyjność & $.44 * * *$ & $.45^{* * *}$ & $.54 * * *$ \\
\hline $\begin{array}{l}\text { Wynik ogólny } \\
\text { ERS }\end{array}$ & $.52 * * *$ & $.43^{* * *}$ & $.57 * *$ \\
\hline
\end{tabular}

$* * p<.01, * * * p<.001$

Źródło: opracowanie własne. oraz że skale Kompetencje zaradcze oraz Refleksyjność będą korelowały dostatecznie silnie ze skalą Kontroli. Analizę korelacji przeprowadzono w grupie młodzieży $(N=211)$ (tabela 7$)$.

Uzyskane wyniki korelacji Pearsona potwierdzają zewnętrzną trafność KERS-14A w grupie młodzieży. Wymiar Repertuar okazał się najsilniej korelować, choć w umiarkowanym stopniu, z ogólnym poziomem elastyczności poznawczej. Korelacje tego czynnika z podskalami elastyczności poznawczej są mniej nasilone. Zaskakujący jest stosunkowo niski wskaźnik powiązań tego wymiaru ze skalą Alternatyw, która zawiera treści dotyczące dostrzegania i generowania rozwiązań w sytuacji trudnej. Skala Kompetencje zaradcze zgodnie z założeniami koreluje najsilniej ze skalą Kontroli, co w pewnym stopniu potwierdza przypuszczenia o monitorowaniu przez młodych ludzi własnych zdolności zaradczych, aby kontrolować efektywność wysiłków zaradczych. Skala Kompetencje zaradcze koreluje również na zbliżonym poziomie ze wskaźnikiem ogólnym elastyczności poznawczej. Refleksyjność u młodzieży ujawnia umiarkowane związki z wynikami w skali Kontroli oraz w skali Alternatyw, a najsilniej jest powiązana z wynikiem ogólnym elastyczności poznawczej.

\section{NORMALIZACJA NARZĘDZIA}

Normalizacja KERS-14A została przeprowadzona bez podziału na płeć, jednolicie dla całej grupy badanej młodzieży ze względu na wcześniej 
opisane niewielkie różnice wynikające z płci w nasileniu elastyczności w radzeniu sobie i jej szczegółowych wymiarach. Normy dla młodzieży ustalono dla grupy 349 osób, w tym 118 chłopców i 231 dziewcząt, w wieku 14-20 lat $(M=17.26 ; S D=1.90)($ tabela 8$)$.

\section{ZASTOSOWANIE KERS-14A}

Kwestionariusz KERS-14A ma zastosowanie w badaniach młodzieży w wieku 14-19 lat, a u młodzieży uczącej się do 20. roku życia. Może być stosowany w badaniach indywidualnych i grupowych osób zdrowych i chorych. Służy do oceny własnej zdolności do poszukiwania i zmiany metod zaradczych w sytuacji trudnej lub stresującej, aby ją efektywnie rozwiązać albo się do niej skutecznie przystosować, łącznie z przyjęciem postawy akceptacji. Umożliwia więc ocenę poziomu zasobów jednostki i jej sprawności w radzeniu sobie. Może to być pomocne w planowaniu działań wspierania rozwoju młodych ludzi w ich kompetencji do radzenia sobie i zarządzania sobą.

Ograniczeniem prezentowanego narzędzia jest określona dotychczas stabilność pomiaru w czasie jedynie dla wyniku ogólnego oraz w odniesieniu tylko do grupy w przedziale wiekowym 19-23 lat. Oznacza to, że w celu prognozowania można korzystać wyłącznie ze wskaźników ogólnego poziomu elastyczności w radzeniu sobie.

Istotne jest także to, że narzędzie dotyczy badanych w okresie intensywnego rozwoju, co oznacza konieczność interpretacji i rozumienia wyników w tym kontekście - sugerują między innymi tendencje w wynikach skali Refleksyjności u młodszych i starszych badanych. Element ewaluacji własnych kompetencji zaradczych, który wyłania się wyraźnie u młodzieży, może być również przejawem realizowanej na tym etapie rozwoju potrzeby kształtowania samoświadomości i dookreślania siebie jako autonomicznej jednostki (Obuchowska, 2002). $\mathrm{W}$ populacji dorosłych odpowiednikiem tego wymiaru jest Zmienność, można więc na tej podstawie przypuszczać, że ta różnica jest przejawem dynamiki kształtowania się kompetencji do elastyczności w radzeniu sobie. Wyjaśnienie uwarunkowań różnic struktury czynnikowej związanych z wiekiem badanych wydaje się szczególnie interesujące, ale wymaga dalszych badań z zastosowaniem KERS-14A.

\section{WNIOSKI}

1. Kwestionariusz Elastyczności w Radzeniu sobie ze Stresem dla Adolescentów pozwala na ocenę elastyczności w podejmowaniu

Tabela 8. Normy dla młodzieży dla KERS-14A $(N=349)$

\begin{tabular}{|c|c|c|c|c|c|c|c|}
\hline \multicolumn{2}{|c|}{$\begin{array}{c}\text { KERS-14A } \\
\text { wynik ogólny }\end{array}$} & \multicolumn{2}{c|}{ Repertuar } & \multicolumn{2}{c|}{ Kompetencje zaradcze } & \multicolumn{2}{c|}{ Refleksyjność } \\
\hline $\begin{array}{c}\text { Wynik } \\
\text { surowy }\end{array}$ & Sten & $\begin{array}{c}\text { Wynik } \\
\text { surowy }\end{array}$ & Sten & $\begin{array}{c}\text { Wynik } \\
\text { surowy }\end{array}$ & Sten & $\begin{array}{c}\text { Wynik } \\
\text { surowy }\end{array}$ & Sten \\
\hline $1-5$ & 1 & 0 & 1 & 0 & 1 & 0 & 1 \\
\hline $6-8$ & 2 & $1-2$ & 2 & 1 & 2 & $1-2$ & 2 \\
\hline $9-13$ & 3 & $3-4$ & 3 & $2-3$ & 3 & 3 & 3 \\
\hline $14-17$ & 4 & $5-6$ & 4 & 4 & 4 & 4 & 4 \\
\hline $18-21$ & 5 & $7-8$ & 5 & 5 & 5 & $5-6$ & 5 \\
\hline $22-25$ & 6 & $9-11$ & 6 & 6 & 6 & 7 & 6 \\
\hline $26-30$ & 7 & $12-13$ & 7 & $7-8$ & 7 & 8 & 7 \\
\hline $31-35$ & 8 & $14-16$ & 8 & $9-10$ & 8 & $9-10$ & 8 \\
\hline $36-38$ & 9 & 17 & 9 & 11 & 9 & 11 & 9 \\
\hline $39-42$ & 10 & 18 & 10 & 12 & 10 & $12-13$ & 10 \\
\hline
\end{tabular}

Źródło: opracowanie własne. 
działań zaradczych wobec sytuacji trudnej oraz na dokonanie oceny jej poszczególnych aspektów związanych ze zmiennością międzysytuacyjną i wewnątrzsytuacyjną w procesie radzenia sobie u młodzieży.

2. Kwestionariusz Elastyczności w Radzeniu sobie ze Stresem dla Adolescentów jest metodą trafną i rzetelną.

3. Inwentarz może być stosowany w badaniach indywidualnych i grupowych mło- dzieży w wieku od 14. do 19. roku życia, a w przypadku młodzieży uczącej się do 20. roku życia.

4. Metoda może być stosowana również w badaniach naukowych do oceny elastyczności w radzeniu sobie w grupie adolescentów.

5. Metoda KERS-14A stanowi narzędzie umożliwiające planowanie kolejnych badań w celu wyjaśnienia uwarunkowań elastyczności w radzeniu sobie u młodzieży.

\section{PRZYPIS}

${ }^{1}$ Wyniki badania osób dorosłych zostały zaprezentowane w odrębnej publikacji (Basińska i in., 2019).

\section{BIBLIOGRAFIA}

Basińska M.A. (2015), Polska wersja Skali Elastycznego radzenia sobie - podsumowanie wyników badań. [Polish version of Coping Flexibility Scale - the summary of research results]. W: M.A. Basińska (red.), Coping Flexibility with Stress in Health and in Disease. Elastyczne radzenie sobie ze stresem $w$ zdrowiu $i$ w chorobie (s. 273-294). Bydgoszcz: Wydawnictwo UKW.

Basińska M.A., Przyborowska-Stankiewicz S., Kruczek A., Liebert A. (2019), Reflective-ruminative tendencies and coping flexibility in patients with non-specific inflammatory bowel diseases. Postepy Psychiatrii i Neurologii, 28(2), 99-115. doi:10.5114/ppn.2019.86254.

Basińska M.A., Woźniewicz A., Warchoł Ł. (2015), Psychological resources and flexibility coping in patients with chronic disorders. W: M.A. Basińska (red.), Coping Flexibility with Stress in Health and in Disease. Elastyczne radzenie sobie ze stresem $w$ zdrowiu $i$ w chorobie (s. 197-215). Bydgoszcz: Wydawnictwo UKW.

Blaauwbroek R., Zwart N., Bouma M., Meyboom-de Jong B., Kamps W.A., Postma A. (2007), The willingness of general practitioners to be involved in the follow-up of adult survivors of childhood cancer. Journal of Cancer Survivorship: Research and Practice, 1(4), 292-297.

Borenstein M., Hedges L.V., Higgins J.P., Rothstein H.R. (2009), Introduction to Meta-Analysis. Hoboken, NJ: John Wiley \& Sons.

Borzyszkowska A., Basińska M.A. (2018). Personal resources - resiliency, hope and spiritual wellbeing in relation to coping flexibility with stress in alcohol dependent persons. Alkoholizm i Narkomania, 31, 4, 243-264.

Brandtstädter J., Renner G. (1990). Tenacious goal pursuit and flexible goal adjustment: Explication and agerelated analysis of assimilative and accommodative strategies of coping. Psychology and Aging, 5, 58-67.

Brzezińska A., Appelt K., Ziółkowska B. (2008), Psychologia rozwoju człowieka. W: J. Strelau, D. Doliński (red.), Psychologia. Podręcznik akademicki. Tom 2 (s.95-292). Gdańsk: Gdańskie Wydawnictwo Psychologiczne.

Brzeziński J. (2012), Metodologia badań psychologicznych. Warszawa: Wydawnictwo Naukowe PWN.

Cheng C. (2001), Assessing coping flexibility in real-life and laboratory settings: A multimethod approach. Journal of Personality and Social Psychology, 80, 814-833.

Cheng C. (2003), Cognitive and motivational processes underlying coping flexibility: A dual-process model. Journal of Personality and Social Psychology, 84, 425-438.

Cheng C., Sun P., Mak K.K. (2015), Internet Addiction and Psychosocial Maladjustment: Avoidant Coping and Coping Inflexibility as Psychological Mechanisms. Cyberpsychology, Behavior and Social Networking, 18(9), 539-546. 
Compas B.E., Conno-Smith J.K., Saltzman H., Thomsen A.H., Wadsworth M.E. (2001), Coping with Stress during Childhood and Adolescence: Problems, Progress und Potential in Theory and Reasearch. Psychological Bulletin, 127, 87-127.

Connor-Smith J.K., Compas B.E. (2002), Vulnerability to Social Stress. Coping as a Mediator of Sociotropy and Symptoms of Anxiety and Depression. Cognitive Therapy and Research, 26, 39-55.

Cooper H. M., Hedges L.V., Valentine J.C. (2009), The Handbook of Research Synthesis and Meta-Analysis (wyd. 2). New York: Russell Sage Foundation.

Delgado-Rico E., Carretero-Dios H., Ruch W. (2012), Content validity evidences in test development: An applied perspective. International Journal of Clinical and Health Psychology Espana, 12(3), $449-460$.

Dempsey M. (2002), Negative coping as mediator in the relation between violence and outcomes: Inner-city African-American youth. American Journal of Orthopsychiatry, 72, 102-109.

Dennis J.P., Vander Wal J.S. (2010), The Cognitive Flexibility Inventory: Instrument Development and Estimates of Reliability and Validity. Cognitive Therapy and Research, 34, 241-253.

Diehl M., Chui H., Hay E.L., Lumley M.A., Grühn D., Labouvie-Vief G. (2014), Change in coping and defense mechanisms across adulthood: Longitudinal findings in a European American sample. Developmental Psychology, 50(2), 634-648.

Evans L.D., Kouros C.D., Samanez-Larkin S., Garber J. (2016), Concurrent and short-term prospective relations among neurocognitive functioning, coping, and depressive symptoms in youth. Journal of Clinical Child and Adolescent Psychology, 45(1), 6-20.

Fu F., Chow A., Li J., Cong Z. (2018), Emotional flexibility: Development and application of a scale in adolescent earthquake survivors. Psychological Trauma: Theory, Research, Practice, and Policy, 10(2), $246-252$.

Góralska K., Basińska M.A. (2019), Resiliency as a predictor of flexibility in coping with stress of cardiac patients. Health Psychology Report. doi:10.5114/hpr.2019.85952

Han G., Helm J., Iucha C., Zahn-Waxler C., Hastings P.D., Klimes-Dougan B. (2015), Are executive functioning deficits concurrently and predictively associated with depressive and anxiety symptoms in adolescents? Journal of Clinical Child and Adolescent Psychology, 53, 1-15.

Heszen-Niejodek I. (2000), Stres i radzenie sobie - główne kontrowersje. W: I. Heszen-Niejodek, Z. Ratajczak (red.), Człowiek w sytuacji stresu. Problemy teoretyczne metodologiczne (s. 12-43). Katowice: Wydawnictwo Uniwersytetu Śląskiego.

Hildebrandt T., Grotzinger A., Reddan M., Greif R., LevyI., Goodman W., Schiller D. (2015), Testing the disgust conditioning theory of food-avoidance in adolescents with recent onset anorexia nervosa. Behaviour Research and Therapy, 71, 131-138.

Hornowska E. (2001), Testy psychologiczne. Teoria i praktyka. Warszawa: Wydawnictwo Naukowe Scholar.

Huxley J.S. (1958), Cultural process and evolution. W: A. Roe, G.G. Simpson (red.), Behavior and Evolution (s. 437-454). New Haven, CT: Yale University.

Jackson Y., Huffhines L., Stone K.J., Fleming K., Gabrielli J. (2017), Coping styles in youth exposed to maltreatment: Longiterdinal patterns reported by youth in foster care. Child Abuse \& Neglect, 70, 65-74.

Janicka M. (2015), Zasoby osobiste a elastyczne radzenie sobie w grupie studentów. [Personal resources and coping flexibility with stress among a group of students]. W: M.A. Basińska (red.), Coping Flexibility with Stress in Health and in Disease. [Elastyczne radzenie sobie ze stresem $w$ zdrowiu $i w$ chorobie] (s. 133-157). Bydgoszcz: Wydawnictwo UKW.

Jones D.R. (2015), Living in the Moment: Daily life assessments of mindfullness mediation on stress, coping flexibility and well-being. Western Washington University Masters Thesis Collection. Paper 422, http:// cedar.wwu.edu/cgi/view-content.cgi?article=1426\&context=wwuet (dostęp: 25 stycznia 2019).

Juczyński Z., Ogińska-Bulik N. (2009), Narzędzia pomiaru stresu i radzenia sobie ze stresem. Warszawa: Pracownia Testów Psychologicznych PTP.

Kato T. (2001), Kopingu-no jyunansei to yokuutukeikou-tono kankei [The relationship between flexibility of coping to stress and depression]. Japanese Journal of Psychology, 72, 57-63.

Kato T. (2012), Development of the coping flexibility scale: Evidence for the coping flexibility hypothesis. Journal of Counseling Psychology, 59(2), 262-289. 
Kato T. (2013), Assessing coping with interpersonal stress: Development and validation of the interpersonal stress coping scale in Japan. International Perspectives in Psychology: Research, Practice, Consultation, 2(2), 100-115.

Kato T. (2014), Relationship between coping with interpersonal stressors and depressive symptoms in the United States, Australia, and China: A focus on reassessing coping. PLoS ONE, 9(10), e109644.

Kato T. (2015), The dual-process theory: New approach to coping flexibility (Teoria podwójnego procesunowe podejście do elastycznego radzenia sobie ze stresem). W: M.A. Basińska (red.), Coping Flexibility with Stress in Health and in Disease. [Elastyczne radzenie sobie ze stresem $w$ zdrowiu $i w$ chorobie] (s. 19-37). Bydgoszcz: Wydawnictwo UKW.

Kato T. (2015a), The impact of coping flexibility on the risk of depressive symptoms. Plos One, 10 (5), e0128307.

Kato T. (2017), Effects of coping flexibility on cardiovascular reactivity to task difficulty. Journal of Psychosomatic Research, 95, 1-6.

Kato T. (2017a), Effects of Flexibility in Coping with Menstrual Pain on Depressive Symptoms. Pain Practice: The Official Journal of World Institute of Pain, 17(1), 70-77.

Krohne H.W., Egloff B., Varner L.J., Burns L.R., Weidner G., Ellis H.C. (2000), The assessment of dispositional vigilance and cognitive avoidance: Factorial structure, psychometric properties, and validity of the Mainz Coping Inventory. Cognitive Therapy \& Research, 24(3), 297-311.

Kruczek A. (2015), Emotion control and anger expression style in relation to coping flexibility in students of middle and secondary schools. W: M.A. Basińska (red.), Coping Flexibility with Stress in Health and in Disease. [Elastyczne radzenie sobie ze stresem w zdrowiu i w chorobie] (s. 95-116). Bydgoszcz: Wydawnictwo UKW.

Kruczek A., Basińska MA., Grzankowska I. (2019), Temperamental determinants of coping flexibility in adolescents. Postepy Psychiatrii i Neurologii, 28(1), 4-20, doi:10.5114/ppn.2019.84354.

Lazarus R.S. (1993), Coping theory and research: Past, present, and future. Psychosomatic Medicine, 55, 234-247.

Lazarus R.S., Folkman S. (1984), Stress, Appraisal, and Coping. Berlin Heidelberg New York: Springer.

Obuchowska I. (2002), Adolescencja. W: B. Harwas-Napierała, J. Trempała (red.), Psychologia rozwoju człowieka. Charakterystyka okresów życia człowieka (s. 163-201). Warszawa: Wydawnictwo Naukowe PWN.

Oleszkowicz A., Senejko A. (2013). Psychologia dorastania. Zmiany rozwojowe w dobie globalizacji. Warszawa: Wydawnictwo PWN.

Pilecka W., Fryt J. (2011). Teoria stresu dziecięcego. W: W. Pilecka (red.), Psychologia zdrowia dzieci i młodzieży. Perspektywa kliniczna (s. 31-48). Kraków: Wydawnictwo Uniwersytetu Jagiellońskiego.

Piórowska A., Banasik A. (2015), Nadzieja a elastyczne radzenie sobie ze stresem u policjantów. [Coping flexibility and hope in police officers group]. W: M.A. Basińska (red.), Coping Flexibility with Stress in Health and in Disease. [Elastyczne radzenie sobie ze stresem $w$ zdrowiu i w chorobie] (s. 175-193). Bydgoszcz: Wydawnictwo UKW.

Piórowski K., Basińska M.A., Piórowska A., Grzankowska I. (2017), Adaptacja Kwestionariusza Elastyczności Poznawczej - Cognitive Flexibility Inventory. Przeglad Psychologiczny, 60(4), 605-620.

Rew L. (2005), Adolescent Health. A Multidisciplinary Approach to Theory, Research, and Intervention. Thousand Oaks, CA: Sage.

Rudnik A., Piotrowicz G., Basińska M.A., Rashedi V. (2019), The importance of cognitive flexibility and flexibility in coping with stress for the quality of life in inflammatory bowel disease patients during biological therapy. A preliminary report. Gastroenterology Review, 14.doi: 10.5114/pg.2018.81081.

Sharif J. (2018), When am I ever going to use this in the real world? Cognitive flexibility and urban adolescents' negotiation of the value of mathematics. Journal of Educational Psychology, 110(5), 726-746.

Soltys M. (2015), Cultural adaptation and psychometric properties of the Coping Flexibility Scale: Current results of polish studies. W: M.A. Basińska (red.), Coping Flexibility with Stress in Health and in Disease. [Elastyczne radzenie sobie ze stresem w zdrowiu i w chorobie] (s. 38-54). Bydgoszcz: Wydawnictwo UKW.

Southward M.W. (2014), The impact of expressive flexibility and context sensitivity on distress (Master's thesis, Arts in the Graduate School of the Ohio State University), https://etd.ohiolink.edu/!etd.send_file? accession $=$ osu14113288630\&disposition=inline (dostęp: 27 lutego 2019). 
Stępka-Tykwińska E., Basińska M.A., Sołtys M., Piórowska A. (2019), Wybrane cechy osobowości funkcjonariuszy państwowej straży pożarnej jako predyktory elastyczności w radzeniu sobie ze stresem. Medycyna Pracy, 70(5), 555-565, doi: 10.13075/mp.5893.00823.

Vowles K.E., McCracken L.M., Sowden G., Ashworth J. (2014), Psychological flexibility in coping with chronic pain: Further examination of the Brief Pain Coping Inventory-2. The Clinical Journal of Pain, 30(4), 324-330.

Vriezekolk J.E., van Lankveld W.G., Eijsbouts A.M., van Helmond T., Geenen R., van den Ende C.H. (2012), The coping flexibility questionnaire: Development and initial validation in patients with chronic rheumatic diseases. Rheumatology International, 32, 2383-2391.

Wallace D.P., Woodford B., Connelly M. (2016), Promoting psychological flexibility in parents of adolescents with chronic pain: Pilot study of an 8-week group intervention. Clinical Practice in Pediatric Psychology, 4(4), 405-416.

Zimmer-Gembeck M.J., Skinner E. (2010), Adolescents coping with stress: Development and diversity. School Nurse News, 27(2), 23-28.

Zong J.G., Cao X.Y., Cao Y., Shi Y.F., Wang Y.N., Yan C., Abela J.R., Gan Y.Q., Gong Q.Y., Chan R.C. (2010), Coping flexibility in college students with depressive symptoms. Health and Quality of Life Outcomes, 8, 66. 


\section{Załącznik 1}

\section{Kwestionariusz Elastyczności w Radzeniu Sobie ze Stresem (KERS-14A) \\ (Małgorzata A. Basińska i zespół)}

Płeć Wiek Wykształcenie.

Klasa.

Ludzie napotykają w swoim życiu na trudne lub stresujące sytuacje, a ich pragnienia i cele nie zawsze mogą być zrealizowane tak, jakby sobie tego życzyli. Każdy człowiek na swój sposób próbuje radzić sobie z takimi sytuacjami, stosując różne sposoby działania i myślenia. Poniższe twierdzenia opisują podejścia do radzenia sobie ze stresem. Przeczytaj proszę każde z nich uważnie. Wskaż, w jakim stopniu każde z nich dotyczy Ciebie, wybierając dla każdego stwierdzenia jedną z następujących odpowiedzi:

0 - nigdy nie dotyczy

1 - czasami dotyczy

2 - często dotyczy

3 - zawsze dotyczy

\begin{tabular}{|c|c|c|c|c|c|}
\hline Lp & TWIERDZENIA & 0 & 1 & 2 & 3 \\
\hline 1 & W stresującej sytuacji widzę wiele różnych rozwiązań. & & & & \\
\hline 2 & $\begin{array}{l}\text { Jeśli nie jestem w stanie zmienić swojej sytuacji, staram się ją zaakcep- } \\
\text { tować. }\end{array}$ & & & & \\
\hline 3 & $\begin{array}{l}\text { Wykorzystuję wiele różnych metod radzenia sobie ze stresem w zależno- } \\
\text { ści od problemu. }\end{array}$ & & & & \\
\hline 4 & $\begin{array}{l}\text { Potrafię zmienić swój sposób radzenia sobie, jeśli w danej sytuacji wyda- } \\
\text { je mi się nieskuteczny. }\end{array}$ & & & & \\
\hline 5 & Wypróbowuję różne sposoby poradzenia sobie ze stresem, aż mi się uda. & & & & \\
\hline 6 & Niezależnie od sytuacji wiem, co zrobić, by poradzić sobie ze stresem. & & & & \\
\hline 7 & $\begin{array}{l}\text { Zmieniam sposób radzenia sobie ze stresem, jeśli moja sytuacja nie ulega } \\
\text { poprawie. }\end{array}$ & & & & \\
\hline 8 & Szukam sposobów, żeby jak najskuteczniej poradzić sobie ze stresem. & & & & \\
\hline 9 & W stresującej sytuacji pytam siebie co jest dla mnie naprawdę ważne. & & & & \\
\hline 10 & $\begin{array}{l}\text { W każdej sytuacji jestem w stanie znaleźć odpowiednie sposoby radzenia } \\
\text { sobie ze stresem. }\end{array}$ & & & & \\
\hline 11 & Zmieniam postępowanie, gdy nieskutecznie radzę sobie ze stresem. & & & & \\
\hline 12 & W trudnej sytuacji daję sobie czas, aby zastanowić się, jak sobie poradzić. & & & & \\
\hline 13 & $\begin{array}{l}\text { Nawet jeśli pojawią się nowe trudności, będę wiedział, jak zmienić swoje } \\
\text { działania, by poradzić sobie. }\end{array}$ & & & & \\
\hline 14 & Gdy nie radzę sobie w trudnej sytuacji - zmieniam swoje podejście. & & & & \\
\hline
\end{tabular}

Rysunek 1. Struktura czynnikowa KERS-14A

Źródło: opracowanie własne 